\title{
Histamine, Metabolic Remodelling and Angiogenesis: A Systems Level Approach ${ }^{\dagger}$
}

\author{
Aurelio A. Moya-García 1,2, ‡®D, Almudena Pino-Ángeles ${ }^{3,4, \ddagger}$, Francisca Sánchez-Jiménez ${ }^{5, \S}$, \\ José Luis Urdiales $1,2,5, * \mathbb{C}$ and Miguel Ángel Medina ${ }^{1,2,5}$ (i)
}

1 Departamento de Biología Molecular y Bioquímica, Universidad de Málaga, 29071 Málaga, Spain; amoyag@uma.es (A.A.M.-G.); medina@uma.es (M.Á.M.)

2 Instituto de Investigación Biomédica de Málaga (IBIMA), 29010 Málaga, Spain

3 Unidad de Lípidos y Arteriosclerosis, Servicio de Medicina Interna, Hospital Universitario Reina Sofia, Instituto Maimonides de Investigación Biomédica de Córdoba (IMIBIC), Universidad de Córdoba, 14004 Córdoba, Spain; almudena.pino@imibic.org

4 Centro de Investigación Biomédica en Red de Fisiopatología de la Obesidad y la Nutrición (CIBEROBN), Instituto de Salud Carlos III, 14004 Córdoba, Spain

5 Centro de Investigación Biomédica en Red de Enfermedades Raras (CIBERER), Instituto de Salud Carlos III, 29010 Málaga, Spain; kikafriky@gmail.com

* Correspondence: jlurdial@uma.es; Tel.: +34-9521-37285

+ To Professor Rafael Peñafiel, in memoriam.

$\ddagger \quad$ These authors contributed equally to this work.

$\S \quad$ Retired; formerly as in affiliations 1 and 2.

Citation: Moya-García, A.A.;

Pino-Ángeles, A.; Sánchez-Jiménez, F.;

Urdiales, J.L.; Medina, M.Á.

Histamine, Metabolic Remodelling and Angiogenesis: A Systems Level Approach. Biomolecules 2021, 11, 415. https://doi.org/10.3390/biom 11030415

Academic Editor: Laura Lucarini

Received: 17 February 2021

Accepted: 8 March 2021

Published: 11 March 2021

Publisher's Note: MDPI stays neutral with regard to jurisdictional claims in published maps and institutional affiliations.

Copyright: (C) 2021 by the authors. Licensee MDPI, Basel, Switzerland. This article is an open access article distributed under the terms and conditions of the Creative Commons Attribution (CC BY) license (https:/ / creativecommons.org/licenses/by/ $4.0 /)$.

\begin{abstract}
Histamine is a highly pleiotropic biogenic amine involved in key physiological processes including neurotransmission, immune response, nutrition, and cell growth and differentiation. Its effects, sometimes contradictory, are mediated by at least four different G-protein coupled receptors, which expression and signalling pathways are tissue-specific. Histamine metabolism conforms a very complex network that connect many metabolic processes important for homeostasis, including nitrogen and energy metabolism. This review brings together and analyses the current information on the relationships of the "histamine system" with other important metabolic modules in human physiology, aiming to bridge current information gaps. In this regard, the molecular characterization of the role of histamine in the modulation of angiogenesis-mediated processes, such as cancer, makes a promising research field for future biomedical advances.
\end{abstract}

Keywords: metabolic remodelling; angiogenesis; systems biology

\section{Histamine Metabolism and its Connections to Other Metabolic Modules}

Histamine (2-(1H-Imidazol-4-yl) ethanamine) is the product of the alpha decarboxylation of the essential amino acid histidine (2-Amino-3-(1H-imidazol-4-yl) propanoic acid) by the enzyme histidine decarboxylase (HDC). Histidine is required in early embryonic stages and during childhood as an exogenous source of histamine, as well as in adults with certain health conditions, such as those caused by the impairment of nitrogen metabolism (i.e., malnutrition, cachexia, hepatic or renal problems, among others). Its synthetic pathway is well known in bacteria [1], hence both dietary proteins and microbiota catalytic activity are the main source for histidine availability. Histidine is also an antioxidant precursor, and its deficiency translates into low levels of histamine, which critically alters the normal functioning of the nervous and immune systems [2-4]. The imidazole ring in histidine acts as electron acceptor/donor in many enzymatic basic-acid reactions, and it is essential in electron transfer systems, oxygen transport, and the function of $\mathrm{Zn}^{2+}$-dependent enzymes and transcription factors, thanks to its ability to form complexes with bivalent metal ions, such as $\mathrm{Fe}^{2+}, \mathrm{Cu}^{2+}, \mathrm{Co}^{2+}, \mathrm{Ni}^{2+}, \mathrm{Cd}^{2+}$, and $\mathrm{Zn}^{2+}$. See the review by Holeček [5] for further information. 
Histamine is not only a key player in allergic reactions but also in vascular permeability, circadian cycle regulation and other neurological and gastric functions, epithelium proliferation, immune cell differentiation, other cardiovascular functions, angiogenesis, and neoplastic progression (Figure 1). Histamine can modify the proteome by degradationderived reactive oxygen species (ROS) that oxidize Cys and Tyr residues, promoting functional alterations that depend on the protein and the physiological status of the cell. Proteins involved in cytoskeleton organization, muscle contraction, inflammation, and cell signalling [6], including G protein-coupled receptors (GPCRs) [7] can also be modified covalently by transglutaminase 2 (TG2), which uses histamine as a substrate [8]. Experiments with HDC KO mice have shown that histamine plays a central role in multiple human pathologies $[9,10]$, although it is still unknown how the elements in the metabolism of histamine are linked to those involved in the development of these conditions.

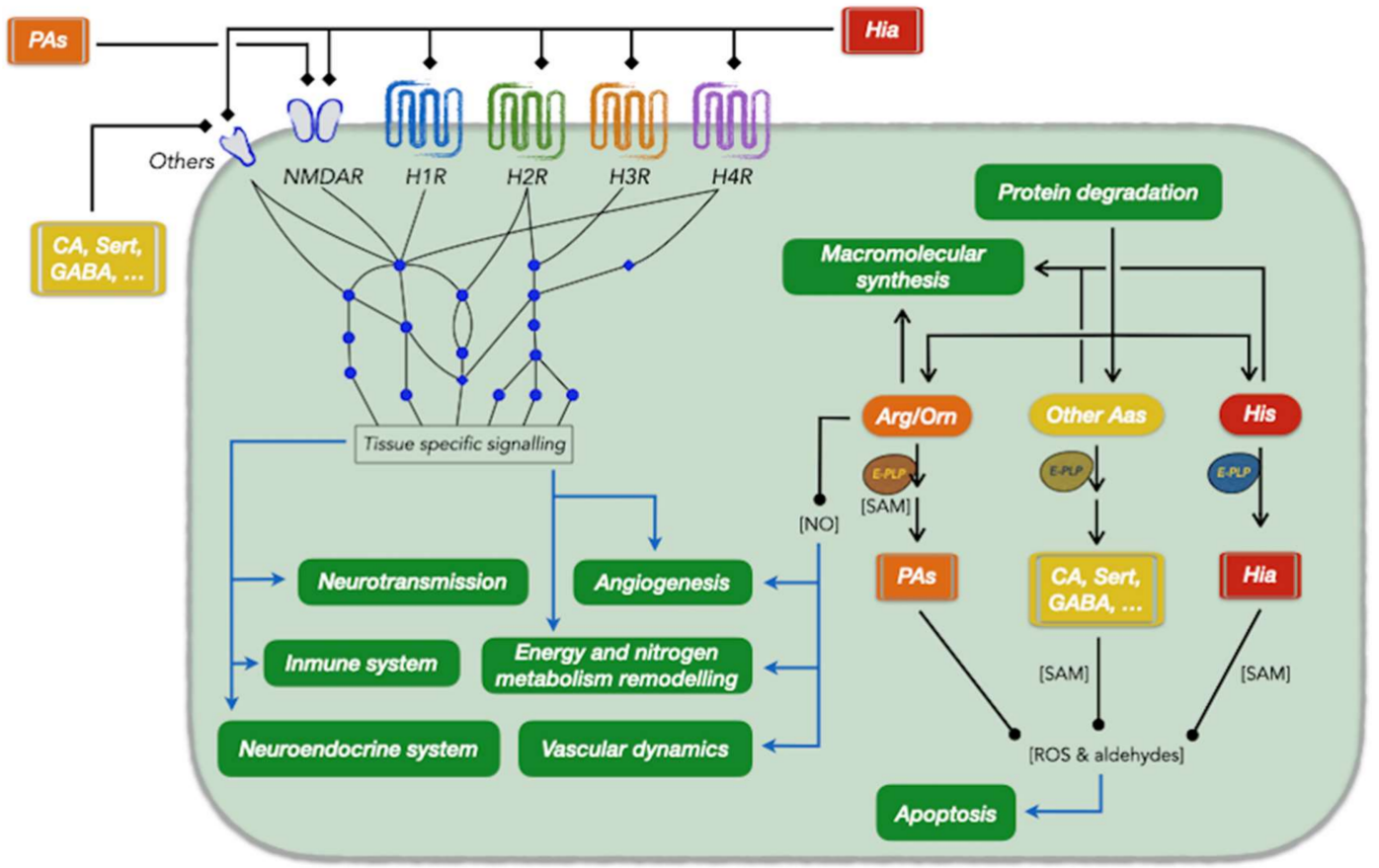

Figure 1. Relationships between histamine and other amines with different physiological and cellular processes. The processes are depicted in green boxes. Abbreviations (by alphabetical order): Aas, amino acids; Arg/Orn, arginine/ornithine; CA, catecholamines; E-PLP, pyridoxal phosphate dependent enzyme; GABA, gamma aminobutyric acid; H1R, histamine receptor 1; H2R, histamine receptor 2; H3R, histamine receptor 3; H4R, histamine receptor 4; Hia, histamine; His, histidine; NMDAR, N-Methyl-D-aspartic acid receptor; NO, nitric oxide; PAs, polyamines; ROS, reactive oxygen species; SAM, S-adenosyl methionine; Sert, serotonin.

At the metabolic level, L-His and histamine are key molecules of nitrogen homeostasis. Histamine metabolism shares metabolites (pyridoxal 5-phosphate, PLP, and S-adenosine methionine, SAM), enzymatic activities (diamine oxidase, DAO, monoamine oxidase, $\mathrm{MAO}$, aldehyde dehydrogenase, and transglutaminase 2) and membrane transporters with the metabolic pathways of other biogenic amines (the diamine putrescine, the polyamines (PA) spermidine and spermine, dopamine and serotonin), and all of them depend on protein intake and endogenous protein synthesis rates (Figure 1). Multiple evidence show that these metabolic pathways also share regulatory mechanisms. Antagonistic time courses of histamine and PA metabolisms have been observed in several pathophysiological scenarios such as in murine mast cells differentiation and basophilic leukemia cells [11-14]. This evidence has been recently reviewed in the context of different pathophysiological scenarios $[15,16]$. The role of biogenic amines in pathologies affecting the neurological and immune systems, mucosa and epithelium renewal and permeability, and fertility (i.e., neurodegenerative diseases, mental retardation, psychiatric disorders, inflammatory 
reactions, food allergies, cancer progression and several rare diseases) should be considered to fully characterize these diseases. We will discuss several links between these metabolic and pathophysiological networks in the context of metabolic remodelling and angiogenesisrelated diseases.

Histamine metabolism is also connected to enzymes of the vitamin B6-dependent family, which use PLP as their cofactor. Among these, there are decarboxylases (including those responsible of other biogenic amines such as dopamine, serotonin, GABA, among others), amino transferases, and other transferases, synthases and lyases [17]. PLP-dependent enzymes are key participants in nitrogen metabolism, including nitrogen homeostasis, the synthesis of neurotransmitters, hormones and neuroendocrine mediators, folate and 1-carbon metabolism, protein and polyamine synthesis, carbohydrate and lipid metabolism, mitochondrial function and erythropoiesis [15]. Hence, vitamin B6 deficit could affect histamine synthesis, as well as other catalytic products of PLP-dependent enzymes, therefore, histamine deficit is a factor to be considered to explain diverse disease phenotypes [18].

Histamine binds to four known G protein-coupled receptors (GPCRs), H1 to H4 receptors, that modulate different signalling pathways [19]. The physiological effects of histamine are dependent on the receptor expressed by each cell type in each physiological context, oftentimes inducing opposite effects on different cell types or cellular status. These facts add further complexity to the analysis and discussion of experimental results. The signalling pathways activated by the four histamine receptors have been reviewed in several recent publications $[15,19]$ and are also summarized in Table 1.

Table 1. Molecular and functional properties of human histamine receptors.

\begin{tabular}{|c|c|c|c|c|}
\hline & H1 Receptor & H2 Receptor & H3 Receptor & H4 Receptor \\
\hline HGNC & HRH1 & HRH2 & HRH3 & HRH4 \\
\hline UniprotKB & P35367 & P25021 & Q9Y5N1 & Q9H3N8 \\
\hline Mass (kDa) & 55.7 & $\begin{array}{c}40.1-44.5 \\
\text { (2 isoforms) }\end{array}$ & $\begin{array}{c}36.4-49.6 \\
\text { (7 isoforms) }\end{array}$ & $\begin{array}{c}34.5-44.5 \\
\text { (2 isoforms) }\end{array}$ \\
\hline Binding affinity & Low $\left(2.5 \times 10^{-5} \mathrm{M}\right)$ & Low $\left(7.9 \times 10^{-6} \mathrm{M}\right)$ & High $\left(6.3 \times 10^{-9} \mathrm{M}\right)$ & High $\left(7.9 \times 10^{-9} \mathrm{M}\right)$ \\
\hline $\begin{array}{l}\text { Cell/tissue } \\
\text { expression }\end{array}$ & $\begin{array}{l}\text { Ubiquitous, brain, smooth } \\
\text { muscle, epithelial and } \\
\text { endothelial cells, immune } \\
\text { cells, hepatocytes and } \\
\text { chondrocytes }\end{array}$ & $\begin{array}{l}\text { Ubiquitous, gastric-mucosa } \\
\text { parietal cells, smooth } \\
\text { muscle, heart, epithelial } \\
\text { and endothelial cells, } \\
\text { immune cells, hepatocytes } \\
\text { and chondrocytes }\end{array}$ & $\begin{array}{c}\text { High expression on } \\
\text { histaminergic neurons }\end{array}$ & $\begin{array}{l}\text { High expression on } \\
\text { bone marrow and } \\
\text { peripheral } \\
\text { hematopoietic cells }\end{array}$ \\
\hline $\begin{array}{l}\mathrm{G}_{\alpha} \text { protein } \\
\text { coupling }\end{array}$ & $\mathrm{G}_{\alpha \mathrm{q} / 11}$ & $\mathrm{G}_{\alpha \mathrm{s}}$ & $\mathrm{G}_{\alpha \mathrm{i} / \mathrm{o}}$ & $\mathrm{G}_{\alpha \mathrm{i} / \mathrm{o}}$ \\
\hline $\begin{array}{l}\text { Signalling } \\
\text { pathways }\end{array}$ & $\begin{array}{l}\text { PLC activation, increase of } \\
\mathrm{Ca}^{2+}, \text { PKC activation, NOS } \\
\text { activation, increase of } \\
\text { cGMP, cAMP accumulation } \\
\text { (via } \mathrm{G}_{\beta \gamma} \text { subunits) }\end{array}$ & $\begin{array}{l}\text { PKA activation, increase of } \\
\text { cAMP, PLC activation, } \\
\text { increase of } \mathrm{Ca}^{2+}\end{array}$ & $\begin{array}{c}\text { Decrease of cAMP, } \\
\text { inhibition of } \mathrm{Ca}^{2+} \\
\text { channels, stimulation } \\
\text { of MAP kinase } \\
\text { phosphorylation }\end{array}$ & $\begin{array}{c}\text { Decrease of cAMP, } \\
\text { inhibition of } \mathrm{Ca}^{2+} \\
\text { channels, stimulation } \\
\text { of MAP kinase } \\
\text { phosphorylation }\end{array}$ \\
\hline $\begin{array}{l}\text { Primary } \\
\text { functions }\end{array}$ & $\begin{array}{l}\text { Immediate allergic } \\
\text { response. Inflammatory } \\
\text { response }\end{array}$ & $\begin{array}{l}\text { Gastric acid secretion. } \\
\text { Suppression of immune } \\
\text { cells. Inflammatory } \\
\text { response }\end{array}$ & $\begin{array}{l}\text { Regulation of arousal } \\
\text { and cognition. Control } \\
\text { of inflammatory } \\
\text { response }\end{array}$ & $\begin{array}{c}\text { Allergic and } \\
\text { inflammatory } \\
\text { responses. Immune cell } \\
\text { chemotaxis }\end{array}$ \\
\hline
\end{tabular}

Data from references [15,19-23].

The rate-limiting step in histamine synthesis is the decarboxylation reaction by HDC, a very instable, short-lived PLP-dependent enzyme homologous to L-aromatic amino acid decarboxylase. In rat stomach, the half-life of HDC activity was $55 \mathrm{~min}$ in controls [24]. The maturation of HDC involves trafficking through the endoplasmic reticulum in a process still not fully characterized, and several proteolytic systems, such as proteasome, m-calpain 
and caspase-9, may be involved in its maturation or degradation [25-29]. The first model of the quaternary structure for the N-terminus of rat HDC (first 512 residues) was obtained by homology modelling and further validated by direct-mutagenesis experiments $[27,30,31]$. The enzyme kinetics and molecular properties were extensively reviewed in 2005 [32]. More recently, the structure of a stable double mutant of the human HDC in complex with the inhibitor histidine methyl esther was solved by X-ray crystallography at $1.8 \AA$ resolution [33]. Both the X-ray structure and computational model are rather coherent in terms of global folding. As of today, the structure of the wild type enzyme has not been solved by any experimental method. A recombinant human fragment (512-N-terminus) of the native rat homodimer-with the maximum activity assayed in vitro [31] — is very instable and exhibit an extremely low $V \max [25,34]$, which suggest that an uncharacterized element could be stabilizing the native dimer conformation in vivo. In addition, further evidence indicates that HDC polypeptide length and the location where it performs is activity in the cell are key factors in the physiology of histamine-producing cells. In fact, the overexpression of an active recombinant version of rat HDC in a human cell-type unable to store histamine, such as HEK or COS cells, alters their proteome with lethal consequences in cell cultures, including increased expression of apoptotic caspases and $\alpha$-synuclein in the case of HK cells [35].

HDC expression is limited to a few cell types: histamine-storing cells (i.e., mast cells, basophils, parietal gastric cells and neurons) and cells that synthetize histamine but cannot store it in specialized vesicles - that is other immune cells such as macrophages, eosinophils and platelets, and several types of cancer cells) [4]. By analysing the HDC expression in different tissues, we observed that the major histamine-producing cells (mast cells, gastric enterochromaffin-like cells and histaminergic neurons) are surrounded by other cell types, promoting a tight relationship with physiological relevance [36-38]. These cells maintain a complex communication that depends on the expression of the histamine receptors, as well as on the own signalling proteome expressed by the histamine-producing cells. For instance, production and secretion of histamine in mast cells is also regulated by PA [39] as well as by the ornithine decarboxylase antizyme inhibitor 2, which is also an activator of PA synthesis and uptake expressed in mast cells [14,40,41].

Histamine synthesis rate depends on the HDC expression regulation, a process which seems to have a strong cell-specific component. Yatsunami et al. [42] located promoter fragments involved in HDC induction by TPA plus dexamethasone and cAMP plus $\mathrm{Ca}^{2+}$ in basophilic cells. HDC regulation in basophilic cells seems to involve several cis-elements such as a TATA-like sequence, a GC box, four CACC boxes, four GATA sequences and 6 leader-binding protein-1 binding motifs, as well as a c-Myb motif, and other positive and negative motifs located in the promoter between positions -497 and -855 in the gene. In ECLC, gastrin is an important HDC inducer [43], involving 3 gastrin-responsive elements. Helicobacter pylori infection activates a MEK1-2/ERK1-2 cascade resulting in gastric HDC induction. However, Kruppel-like factor, Ying-yang and SREBP act as repressors of HDC expression $[44,45]$. Promoter methylation also seems to play an important role in regulation of HDC expression in different cell types, a mechanism that seems to be dependent of specific cell differentiation programs and cell metabolic status [46,47]. In differentiated histamine-producing cells, HDC expression is regulated by different signalling pathways, which coordinates histamine production with its physiological function (immune response, gastric acid secretion, neurotransmission, cancer progression) in differentiated cell types. Current information on the regulatory mechanisms of histamine synthesis in inflammatory and gastric cells has been provided by Wang and collaborators. Nevertheless, knowledge on HDC transcriptional regulation in differentiated human cell types still is an open subject of study with important gaps in tissue-specific information [15,48].

Histamine can be degraded by two different pathways in mammalian cells. On one hand, N-methyl transferase (HNMT) carries out the intracellular N-methylation of the imidazole group, using SAM as the methyl donor [49]. HNMT is a 33kDa monomeric protein, A human recombinant version being solved by X-ray chrystallography, Its ac- 
tivity is sensible to $\mathrm{SH}$-group reagents [50,51]. Its gene is poorly characterized and lacks canonical promoter cis-elements such as TATA and CAAT boxes [52]. The activity links histamine degradation to the availability of SAM, and to the synthesis of polyamines, and folates/methionine recycling [53,54], which is involved in the methylation of proteins and nucleic acids, being therefore relevant for the regulation of gene expression and epigenetics. HNMT is mainly expressed in liver and seems to be the major histamine degradation pathway in the brain [15]. The product N-tele methyl-histamine is a substrate of MAO-B, which produces oxygen peroxide and $\mathrm{N}$-methylimidazole acetaldehyde. MAO-B is a member of the flavin monoamine oxidase family, located in the mitochondrial outer membrane. It is expressed mainly in liver and other tissues in a minor extent [55]. In regulation of its transcription, the complex Sp1/Egr1/CREB, as well as microRNAs miR-1224 and miR-300, seem to be involved [56]. In other tissues, such as the gastrointestinal tract, histamine is oxidized by DAO, a cytosolic membrane-associated protein that produces imidazole acetaldehyde and oxygen peroxide [49]. This enzyme has also be detected in body fluids $[57,58]$. It is worth mentioning that mucosal mono- and polyamine oxidase activities are distributed complementary to diamine oxidase in digestive tract [59]. Whatever the degradation pathway is, histamine is a source of reactive oxygen species (ROS) that can cause macromolecular damage and aging, especially if the microenvironment is poor in antioxidant molecules. In other cases, reversible protein oxidation by ROS can have beneficial effects for certain cell types; for instance, preconditioning neurons to ischemia [60].

\section{Histamine and Vessel Dynamics}

It is well known that alterations in vessel dynamics and vascular permeability are tightly connected with angiogenesis [61]. As early as 1948, histamine was seen to increase the vascular permeability at the haemato-ocular barrier [62], and just three years later, Miles showed that histamine increases the permeability of skin capillaries in guinea pigs [63]. Several studies published in the following years confirmed and reinforced these findings [64-67], and shed light into the molecular mechanisms, including the roles of protein kinases, cytosolic calcium, cAMP and actin cytoskeleton [68,69]. Guo et al. showed that histamine causes a transient and reversible disruption of the VE-cadherin/beta-catenin binding during the hyperpermeability response induced by histamine on endothelial cells [70]. The increase in vascular permeability induced by histamine through histamine H1 receptor had a direct effect on vascular permeability for low-density lipoproteins, thus promoting the formation of atherosclerotic lesions [71].

$\mathrm{H} 3$ and $\mathrm{H} 4$ receptors are also expressed by endothelial cells, so there might be other potential effects of histamine on vascular permeability and vessel dynamics still unknown [72] The role of histamine in vascular leakage and dysfunction is mediated by RhoA and ROCK [73-75]. RhoA activation induced by histamine is associated to a fast $\mathrm{Ca}^{2+}$ influx and the breakdown of microvascular endothelial cell barriers [76]. In lymphatic endothelial cells, this movement of $\mathrm{Ca}^{2+}$ is mediated by $\mathrm{Ca}^{2+}$ release-activated $\mathrm{Ca}^{2+}$ channels (CRAC), suggesting that CRAC could be a target for inhibitors able to relieve histamine-triggered vascular leakage [77].

Recently, Grimsey et al. [78] have shown that histamine induce a robust p38 autophosphorylation in endothelial cells, acting through H1R/H2R. This involves the non-canonical TAB1-TAB2/3 dependent pathway, thus promoting endothelial inflammatory responses. This agrees with our previous observations on the anti-inflammatory effects of epigallocatechin gallate (EGCG), an inhibitor of HDC, on mast cells and monocytes [79,80].

\section{Histamine, Metabolic Reprogramming and Angiogenesis: Pathophysiological Implications}

Cell proliferation and differentiation in different pathophysiological scenarios, such as gestation or cancer progression, are the most relevant processes subject to metabolic reprogramming induced by histamine. Only the cells able to adapt their metabolic networks to the pressure posed in such processes can keep its own homeostasis and survive. 


\subsection{Histamine and Angiogenesis in Gestation}

Biogenic amines have regulatory roles in the metabolic changes and complex cellular communication events that occur during gestation, i.e., energy and nitrogen metabolism remodelling, adaptation to hypoxia, extracellular matrix remodelling, endothelial and immune cell differentiation, and the production, secretion, and reception of mast cells mediators [12,81-83].

Histamine levels modulate embryo-uterine interactions, so either low or excessively high levels might lead to gestational complications $[84,85]$. Histamine seems to have a regulatory role in trophoblast differentiation-a process that involves the expression of integrin aV-b3 and trophoblastic H1R, which seems to be involved in vascular invasion and placenta neovascularization [86]. Further research suggests that histamine-induced tissues remodelling favours embryo implantation, assisted by several molecular mediators released by infiltrated mast cells [87]. Those infiltrated mast cells present in the placental bed are involved in immune regulatory functions, the regulation of trophoblast invasion, in angiogenesis and in vessel remodelling [88].

\subsection{Histamine in Cancer}

The involvement of histamine in different cancer types has been extensively reviewed $[89,90]$. Histamine can participate in several of the hallmarks of cancer introduced by Hanahan and Weinberg [91]. Histamine can induce cancer cell proliferation or cell death depending on the receptors expressed by the target cells. This includes autocrine effects, since some cancer cells are also histamine-producing cells (as for instance, malignant mastocytosis [92], breast cancer [93], or gastric cancer [94]), and paracrine effects between cancer cells and the histamine-producing immune cells-including those that produce histaminein the tumour microenvironment [37]. H1R-elicited signals have been considered mainly as antiproliferative stimuli; the opposite role has been proposed by histamine when acting through H2R, however some controversial results were obtained in vivo $[93,95,96]$. The latest discovered histamine receptor (H4R) also seems to be an important element for modulation of carcinogenesis and/or cancer progression. Working with breast cancer, H4R agonists reduce several markers of tumour progression in vivo [97]. It is interesting that both tumour and immune cells can express H4R, suggesting that histamine acting through H4R could be a coordinator of the crosstalk between immune and breast cancer cells in vivo. Similar results were obtained for H4R working with melanoma cell lines [98]. The results could indeed have translational potential, but further characterization of the signalling at molecular level is still needed [90]. This complex intercellular interactome must plays very important roles in the development of several hallmarks of cancer different from those related with cancer growth (sustaining proliferative signalling and evading growth suppressors). For instance, histamine enables the tumour to suppress the immune response from the tumour environment and promotes inflammation, leading to invasion, metastasis, and angiogenesis with the participation of cytokines and proteases [99,100].

\subsection{Histamine and Angiogenesis}

A deregulated angiogenesis is casually involved in many diseases, including cancer, ophthalmic diseases, arthritis, psoriasis and almost 200 rare diseases [101,102]. The role of histamine in angiogenesis, was first suggested in 1983 when Fraser and Simpson showed that histamine produced by mast cells induces neovascularization in a chorioallantoic membrane model; however, this induction was not replicated by Barnhill and Ryan who reported negative results with histamine $0.1 \mathrm{mM}[103,104]$. Further research supported the indirect inductive effect of histamine on angiogenesis $[105,106]$, mediated by H1R and H2R [107]. The effect of histamine and serotonin in angiogenesis is biphasic: micromolar concentrations of histamine give rise to a quick pro-angiogenic response via TR3/NUR77, but induce a negative feed-back loop after 10 days by upregulating the potent anti-angiogenic endogenous compound thrombospondin-1 [108]. 
Endogenous histamine has a dual role (activation/inhibition) in the regulation of angiogenesis [109]. The effects of histamine produced by mast cells have been reviewed in depth [110-112] and they are dependent on the activity of several transcription factors, including NR4A1, MYCN and RCAN1, [113]. The role of H1R and H2R is also well established, where the synergistic effect of histamine and bFGF mediated by H1R increases VEGF levels and thus induces angiogenesis [114]. Furthermore, the H2R antagonist cimetidine inhibits angiogenesis [115].

\section{A Systems Biology Approach to Histamine as a Modulator of Metabolic Reprogramming}

The large amount of evidence gathered from traditional biochemical and cellular biology experiments together with the latest generalized use of -omics techniques have revealed that molecular functions and phenotypes can be no longer understood as isolated events. The intricate reality of human pathophysiology has prompted the use of systemic approaches to study the intertwined molecular mechanisms underlying health and disease [116]. Contrary to classic pharmacology approaches, the tools in Systems Biology allow us to move past the traditional paradigm of "one gene-one protein (target)-one drug". Systems Biology explores the complex networks of molecular interactions and signaling controlling the biological functions, and by extension, Systems Pharmacology will assess what elements in these networks need to be modulated to regulate precisely and effectively the outcome of such functions. Systems Biology is then essential in the development of successful personalized therapies, especially in multifactorial conditions that have large variability between individuals.

In previous sections, histamine has been shown to have a potential role in the metabolic remodelling of cancer cells. Through histamine receptors, histamine can influence several hallmarks of cancer, and participate in important processes underlying tumour progression and metastasis, such as angiogenesis and inflammation. However, the many molecular pathways by which histamine operates often branch and crosstalk, making up an intricate network of molecular interactions. The complexity of such interactions makes the characterisation of histamine pathways a challenging task that can be tackled by Systems biology approaches.

We have modelled the network of signalling interactions between the histamine receptors and the key metabolic modulators in the tumour microenvironment (compiled and reviewed in [117]) to gain insight of the potential role of histamine in tumour metabolic reprogramming. We compiled the signalling interactions from well-regarded data repositories: the Atlas of Cancer Signalling Networks [118], the Cancer Cell Map [119], PhosphoSite [120], the Signalling Network Open Resource [121], the Human Cancer Signalling Network [122], and OmniPath [123]; from which we modelled the network of signalling interactions between the histamine receptors and the genes involved in reprogramming cancer metabolism, so we obtained a general view of how histamine participates in reprogramming tumour metabolism. Table 2 and Figure 2 show that histamine receptors are connected through signalling interactions with genes involved in disparate signalling pathways that regulate the cellular metabolism, glycolysis, the TCA cycle and oxidative phosphorylation, the synthesis of lipids and nucleic acids, and in particular, the metabolism of polyamines and amino acids. 
Table 2. A synthesis of biochemical characteristics of metabolic remodelling-related targets modified by histamine through $\mathrm{H} 1-\mathrm{H} 4$ receptors.

\begin{tabular}{|c|c|c|c|c|}
\hline Protein & HGNC & UniprotKB & Biological Function & $\begin{array}{l}\text { Metabolism } \\
\text { Remodelling }\end{array}$ \\
\hline hexokinase 1 & HK1 & P19367 & $\begin{array}{l}\text { Key glycolytic enzyme responsible of hexose } \\
\text { phosphorylation, also involved in release of } \\
\text { mitochondrial pro-apoptosis elements. }\end{array}$ & \\
\hline hexokinase 2 & HK2 & P52789 & $\begin{array}{c}\text { Key glycolytic enzyme responsible of hexose } \\
\text { phosphorylation }\end{array}$ & Glycolysis \\
\hline $\begin{array}{l}\text { 6-phosphofructo-2- } \\
\text { kinase/fructose-2,6- } \\
\text { biphosphatase } 3\end{array}$ & PFKFB3 & Q16875 & $\begin{array}{l}\text { Key enzyme for glycolysis regulation. Proposed as a } \\
\text { marker to distinguish between induced-pluripotent stem } \\
\text { cells and cancer stem cells. Its expression is modified } \\
\text { by hypoxia }\end{array}$ & \\
\hline $\begin{array}{c}\text { pyruvate } \\
\text { dehydrogenase kinase } \\
1\end{array}$ & PDK1 & O15530 & $\begin{array}{l}\text { It activates by phosphorylation targets such as AKT1, } \\
\text { PRKACA, involved in glucose and nitrogen uptake y } \\
\text { storage. It can inhibit TGF- } \beta \text { signalling, as well as } \\
\text { activate NF-kB in macrophages and calcium movements } \\
\text { in mast cells. Regulator of key nutrient receptor in } \\
\text { thymocytes, and essential for mobility of vascular } \\
\text { endothelial cells. }\end{array}$ & TCA cycle \\
\hline cytochrome c & CYCS & P99999 & $\begin{array}{l}\text { Electron carrier protein that plays a role in the } \\
\text { mitochondrial-associated mechanism of apoptosis }\end{array}$ & OXPHOS \\
\hline $\begin{array}{l}\text { phosphoglycerate } \\
\text { mutase } 1\end{array}$ & PGAM1 & P18669 & $\begin{array}{l}\text { Glycolytic enzyme described as a promising target for } \\
\text { diagnosis and therapy of cancer }\end{array}$ & $\begin{array}{l}\text { Pentose } \\
\text { phosphate } \\
\text { pathway }\end{array}$ \\
\hline $\begin{array}{l}\text { SLC7A8 amino acid } \\
\text { transporter light chain, } \\
\text { L system }\end{array}$ & LAT2 & Q9UHI5 & $\begin{array}{l}\text { Neutral amino acid cytosolic exchanger. It is involved in } \\
\text { glutamine-dependent mTOR activation to promote } \\
\text { glycolysis in cancer cells. }\end{array}$ & \\
\hline $\begin{array}{l}\text { solute carrier family } 38 \\
\text { member } 2\end{array}$ & SLC38A2 & Q96QD8 & $\begin{array}{l}\text { It has glutamine as a ligand, and is involved in cellular } \\
\text { response to starvation, regulation of gene expression and } \\
\text { splicing, and cellular response to stress. }\end{array}$ & $\begin{array}{l}\text { Amino acid } \\
\text { metabolism }\end{array}$ \\
\hline $\begin{array}{l}\text { solute carrier family } 7 \\
\text { member } 1\end{array}$ & SLC7A1 & P30825 & $\begin{array}{l}\text { It accepts L-Arg, L-ornithine, L- His and L- Lys } \\
\text { as substrates. }\end{array}$ & \\
\hline $\begin{array}{l}\text { potassium inwardly } \\
\text { rectifying channel } \\
\text { subfamily J member } 11\end{array}$ & KCNJ11 & Q14654 & $\begin{array}{l}\text { It acts as a transmembrane transport system and an } \\
\text { ankyrin-binding protein. It is Involved in cardiac muscle } \\
\text { function, ischemia response and glucose homeostasis. }\end{array}$ & \\
\hline $\begin{array}{l}\text { spermidine/spermine } \\
\text { N1-acetyltransferase } 1\end{array}$ & SAT1 & P21673 & $\begin{array}{c}\text { Key enzyme for polyamine degradation. } \\
\text { Highly regulated. }\end{array}$ & $\begin{array}{l}\text { Polyamine } \\
\text { metabolism }\end{array}$ \\
\hline spermine synthase & SMS & P52788 & $\begin{array}{l}\text { Enzyme responsible of spermine synthesis from } \\
\text { spermidine and decarboxylated S-adenosylmethionine. } \\
\text { Diminished activity is related to } \\
\text { Snyder-Robinson syndrome. }\end{array}$ & \\
\hline $\begin{array}{l}\text { Fas cell surface } \\
\text { death receptor }\end{array}$ & FAS & P25445 & $\begin{array}{l}\text { Key element for extrinsic apoptosis pathway. Related to } \\
\text { regulation of immune response. }\end{array}$ & Lipid synthesis \\
\hline $\begin{array}{l}\text { amyloid beta precursor } \\
\text { protein binding family } \\
\text { B member } 1\end{array}$ & APBB1 & PO00213 & $\begin{array}{l}\text { Transcription coregulator related to histone } \\
\text { postranslational modifications, and regulation of many } \\
\text { key elements for cell division and apoptosis. } \\
\text { Key element for biomolecular methylations important } \\
\text { for DNA synthesis and gene expression, among many } \\
\text { other processes. }\end{array}$ & $\begin{array}{l}\text { Nucleic acid } \\
\text { metabolism }\end{array}$ \\
\hline
\end{tabular}


Table 2. Cont.

\begin{tabular}{|c|c|c|c|c|}
\hline Protein & HGNC & UniprotKB & Biological Function & $\begin{array}{l}\text { Metabolism } \\
\text { Remodelling }\end{array}$ \\
\hline ankyrin 1 & ANK1 & P16157 & $\begin{array}{c}\text { Structural protein related to cytoskeletal remodelling, } \\
\text { and organelle organization. }\end{array}$ & \\
\hline $\begin{array}{l}\text { eukaryotic translation } \\
\text { initiation factor } 2 \text { alpha } \\
\text { kinase } 2\end{array}$ & EIF2AK2 & P19525 & $\begin{array}{c}\text { Protein kinase acting as an inhibitor of viral infection via } \\
\text { the integrated stress response. Also involved in } \\
\text { regulation of apoptosis and cell proliferation, and } \\
\text { inflammatory response. }\end{array}$ & \\
\hline $\begin{array}{l}\text { hypoxia inducible } \\
\text { factor } 1 \text { subunit alpha }\end{array}$ & HIF1A & Q16665 & $\begin{array}{c}\text { Under hypoxia, it activates a plethora of genes, involved } \\
\text { in embryonic vascularization and tumour angiogenesis. } \\
\text { Also related to response to virus infections, including } \\
\text { SARS-CoV-2. }\end{array}$ & \\
\hline $\begin{array}{l}\text { mechanistic target of } \\
\text { rapamycin kinase }\end{array}$ & MTOR & P42345 & $\begin{array}{c}\text { Central regulator of cellular metabolism, growth and } \\
\text { survival in response to hormones, growth factors, } \\
\text { nutrients, energy and stress signals. }\end{array}$ & \\
\hline Endonuclease 8-like 1 & NEIL1 & Q96F14 & $\begin{array}{c}\text { Involved in base excision repair of DNA damaged by } \\
\text { oxidation or by mutagenic agents. }\end{array}$ & \\
\hline Plasminogen & PLG & P00747 & $\begin{array}{c}\text { Plasmin precursor. Plasmin acts as a proteolytic factor in } \\
\text { a variety of other processes including ovulation, } \\
\text { embryonic development, tissue remodelling, tumour } \\
\text { invasion, and inflammation. }\end{array}$ & $\begin{array}{l}\text { Metabolic- } \\
\text { signaling } \\
\text { pathways }\end{array}$ \\
\hline $\begin{array}{l}\text { protein kinase } \\
\text { cAMP-activated } \\
\text { catalytic subunit alpha }\end{array}$ & PRKACA & P17612 & $\begin{array}{l}\text { This kinase is involved in many processes related to fuel } \\
\text { (glucose and lipid) metabolism, cell differentiation of } \\
\text { different cell-types, and immune cells responses, } \\
\text { including inflammation. When activated inhibits the } \\
\text { antiproliferative and antiinvasive effect of } \\
\text { difluoromethylornithine (an inhibitor of } \\
\text { polyamine synthesis). }\end{array}$ & \\
\hline $\begin{array}{l}\text { protein kinase } \\
\text { cAMP-dependent type } \\
\text { I regulatory } \\
\text { subunit alpha }\end{array}$ & PRKAR1A & P10644 & $\begin{array}{l}\text { Subunit responsible of the regulation of } \\
\text { cAMP-dependent protein kinase, whose properties are } \\
\text { briefly described above. }\end{array}$ & \\
\hline $\begin{array}{l}\text { von Hippel-Lindau } \\
\text { tumor suppressor }\end{array}$ & VHL & P40337 & $\begin{array}{l}\text { Involved in the ubiquitination and subsequent } \\
\text { proteasomal degradation of proteins. It is involved in } \\
\text { transcriptional repression through interactions with } \\
\text { H1F1A, HIF1AN and histone deacetylases. }\end{array}$ & \\
\hline
\end{tabular}

Data from UniProt Knowledgebase and reference [117].

As expected, some of the targets of signalling interactions from histamine receptors are involved in immune response: ANK1, EIF2AK2, HIF1A, PDK1, PRKACA, PRKAR1A and VHL. We postulate that the signalling exerted by histamine would be relevant in the crosstalk between proliferating cancer cells and immune cells present in the tumour microenvironment. We observe that histamine can influence the shift from aerobic to anaerobic glucose metabolism that cancer cells deploy in response to proliferation stimuli [124], by influencing key regulators of glucose metabolism such as HK1, HK2, PDK1, PRKACA and PFKFB3. Histamine could mediate signalling effects on the mitochondria function and integrity through CYCS, hexokinase isozymes, and mTOR.

The metabolism of histamine and the biogenic polyamines are related to each other in some cell types. We have modelled their interactions-including the crosstalk with sulphur metabolism - that provided deeper insights on the connections of polyamines with energy metabolism $[47,53,125]$. In our network models, it can be observed how histamine connects with polyamines metabolism through spermine synthase (SMS) and spermidine/spermine acetyl transferase (SAT1) and the cationic amino acid transporter (SLC7A1), which have been described previously in cancer cell models [16,126]. 


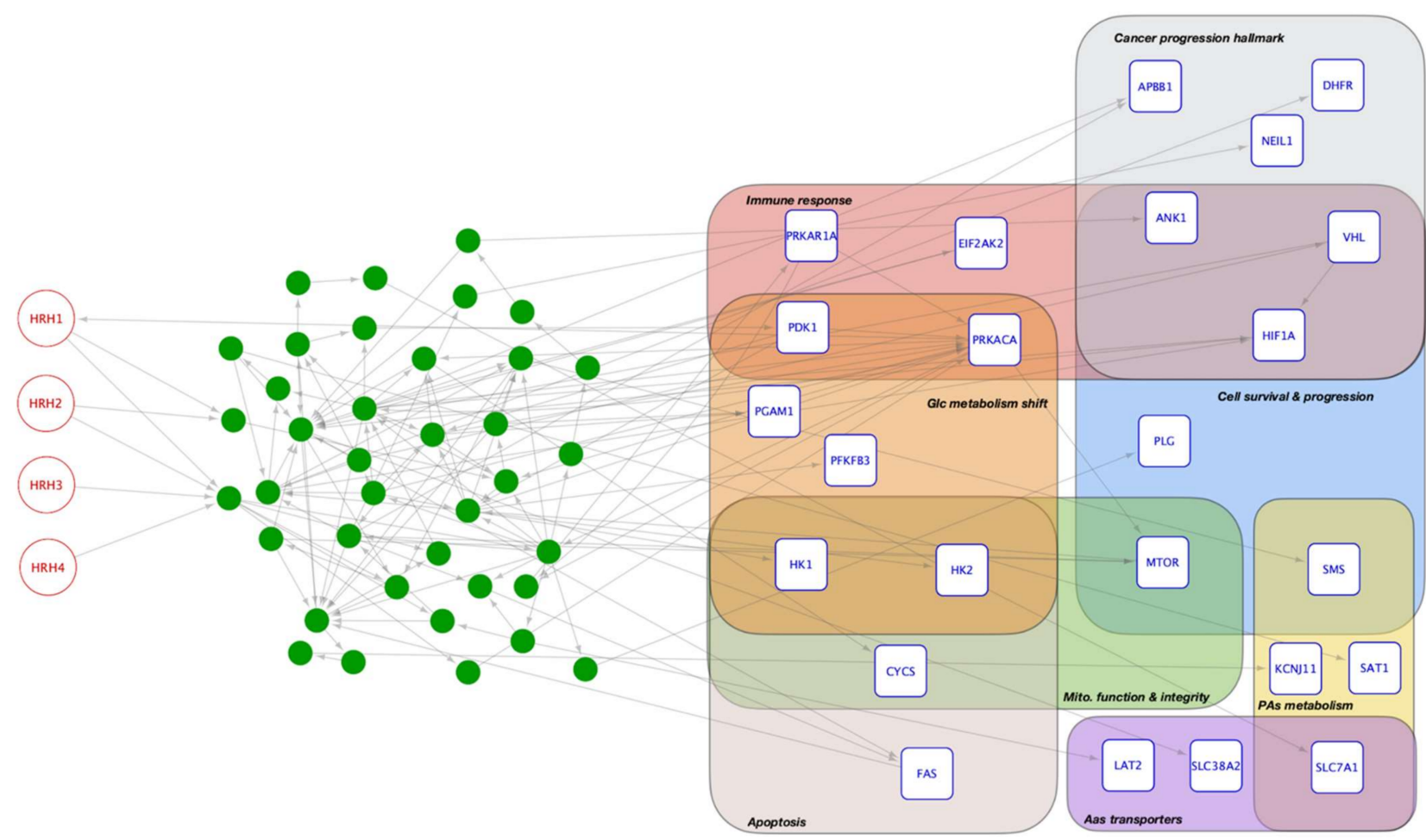

Figure 2. Network of signaling interactions between the histamine receptors and the genes involved in reprogramming cancer metabolism. Abbreviations used as in Table 2.

Furthermore, our network analysis supports previous evidence that histamine can sway the metabolism of both polyamines and amino acids, including those essential for cancer cell growth such as glutamine, arginine, methionine and ornithine [127]. However, the signalling effect of histamine on polyamines and amino acid metabolism comes up mainly by histamine influencing polyamines and amino acids transporters (see Table 2). This observation remarks the importance of the metabolic compartments for understanding biochemical and physiological processes [128].

Our histamine signalling network provides further details on the ambiguous role histamine plays on regulating both cell proliferation and cell death. On the one hand, histamine participates in the regulation of apoptosis acting upon CYCS, FAS, and hexokinases. On the other hand, histamine can influence cell survival and cell proliferation pathways by way of key elements such as mTOR, HIF1A, SMS, and VHL, together with elements of cancer progression hallmarks-ANK1, involved in cytoskeleton remodelling, DHFR in genome methylation, NEIL1 in genome edition, APBB1 and VHL in chromatin covalent modification, and the remarkable role of HIF1A as coordinator of different cancer hallmarks [129].

\section{Concluding Remarks and Future Prospects}

The complex system we termed the histamine influence network has several remarkable features. Its basic metabolism (synthesis and degradation) consists of simple pathways composed by a few reactions. However, the expression of key enzymes is cell type specific, and their regulation is not well characterised in the different cell types. These metabolic reactions share elements with other biochemical pathways and can therefore take part in processes such as SAM-dependent methylation of amino acids and amines, and posttranslational protein covalent modification, thus expanding the histamine metabolic network.

Besides synthesis and degradation, metabolism also includes intercellular signalling, adding further complexity to the histamine network. Since histamine receptors are expressed in different cell types, activate different $G$ proteins and show different affinity for histamine (Table 1), histamine can conform an extremely complex metabolic network that 
modulates the key physiological processes at the organism level. The greater advances in biomedicine and pharmacology regarding histamine-mediated pathologies focus almost exclusively on allergic and immune reactions, neurotransmission and digestion. However, the many data and information gaps that remain on this complex system hampers the development of efficient intervention strategies in many other diseases.

In this work, we have outlined the current perspective on different layers of the network where the role of histamine is clear, with our focus on unveiling further details on cell proliferation, tissue growth and cancer progression.

Tumour development requires distinct metabolic phenotypes to support their proliferation and progression, especially in both nitrogen and energy metabolism. Cell signalling is fundamental to understand this metabolic reprogramming, but a full view combining the known individual signalling pathways is still missing. We have provided a glance of how histamine is involved in the coordination of some signalling processes. That is, our network analysis brings an interesting starting point to get further insights in the reprogramming of the metabolism needed for the processes we have discussed in this review.

We propose that Systems Biology approaches are essential to fill the gaps of information about histamine signalling in different pathophysiological scenarios, and to assist the diagnosis and to locate intervention targets of multiple human syndromes and diseases [130]. Our work provides a general picture on how histamine can influence angiogenesis and cancer metabolic reprogramming, though the actual role of histamine will depend on its local concentrations, and the sets of these genes expressed in each cell type involvedin particular the histamine receptors. Experimental approaches using co-cultures or genetic modified organisms, together with transcriptomic, proteomic, metabolomics, and biochemical and biophysical analyses, will also be essential and complementary to understand the effects of histamine in different cell types and physiological conditions.

Author Contributions: Conceptualization, A.A.M.-G., A.P.-Á., F.S.-J., J.L.U. and M.Á.M.; methodology, A.A.M.-G. and A.P.-Á.; formal analysis, A.A.M.-G., A.P.-Á., F.S.-J., J.L.U. and M.Á.M.; writingoriginal draft preparation, A.A.M.-G., A.P.-Á., F.S.-J., J.L.U. and M.Á.M.; writing-review and editing, A.A.M.-G., A.P.-Á., F.S.-J., J.L.U. and M.Á.M.; supervision, F.S.-J. and M.Á.M. All authors have read and agreed to the published version of the manuscript.

Funding: The experimental work carried out by our group is supported by grants PID2019-105010RBI00 (Spanish Ministry of Science, Innovation and Universities), and UMA18-FEDERJA-220 (Andalusian Government and FEDER) and funds from group BIO 267 (Andalusian Government). The "CIBER de Enfermedades Raras" and "CIBER de Fisiopatología de la Obesidad y la Nutrición" are an initiative from the ISCIII (Spain).

Acknowledgments: This work is devoted to the memory of Rafael Peñafiel.

Conflicts of Interest: The authors declare no conflict of interest.

\section{References}

1. Ramos-Montañez, S.; Winkler, M.E. Biosynthesis of Histidine. EcoSal Plus 2009, 3. [CrossRef]

2. Yoshikawa, T.; Nakamura, T.; Shibakusa, T.; Sugita, M.; Naganuma, F.; Iida, T.; Miura, Y.; Mohsen, A.; Harada, R.; Yanai, K. Insufficient Intake of 1-Histidine Reduces Brain Histamine and Causes Anxiety-Like Behaviors in Male Mice. J. Nutr. 2014, 144, 1637-1641. [CrossRef]

3. Panula, P.; Sundvik, M.; Karlstedt, K. Developmental roles of brain histamine. Trends Neurosci. 2014, 37, 159-168. [CrossRef]

4. Stark, H. (Ed.) Histamine H 4 Receptor: A Novel Drug Target for Immunoregulation and Inflammation; Versita: Berlin, Germany, 2013; ISBN 9788376560564.

5. Holeček, M. Histidine in Health and Disease: Metabolism, Physiological Importance, and Use as a Supplement. Nutrients 2020, 12, 848. [CrossRef]

6. Lai, T.-S.; Lin, C.-J.; Greenberg, C.S. Role of tissue transglutaminase-2 (TG2)-mediated aminylation in biological processes. Amino Acids 2017, 49, 501-515. [CrossRef] [PubMed]

7. Vowinckel, J.; Stahlberg, S.; Paulmann, N.; Bluemlein, K.; Grohmann, M.; Ralser, M.; Walther, D.J. Histaminylation of glutamine residues is a novel posttranslational modification implicated in G-protein signaling. FEBS Lett. 2012, 586, 3819-3824. [CrossRef] [PubMed] 
8. Qiao, S.W.; Piper, J.; Haraldsen, G.; Oynebraten, I.; Fleckenstein, B.; Molberg, O.; Khosla, C.; Sollid, L.M. Tissue transglutaminasemediated formation and cleavage of histamine-gliadin complexes: Biological effects and implications for celiac disease. J. Immunol. 2005, 174, 1657-1663. [CrossRef]

9. Ohtsu, H. Histamine synthesis and lessons learned from histidine decarboxylase deficient mice. Adv. Exp. Med. Biol. 2010, 709, 21-31. [PubMed]

10. Ohtsu, H. Pathophysiologic Role of Histamine: Evidence Clarified by Histidine Decarboxylase Gene Knockout Mice. Int. Arch. Allergy Immunol. 2012, 158, 2-6. [CrossRef]

11. Fajardo, I.; Urdiales, J.L.; Paz, J.C.; Chavarría, T.; Sánchez-Jiménez, F.; Medina, M.Á. Histamine prevents polyamine accumulation in mouse C57.1 mast cell cultures. Eur. J. BioChem. 2001, 268, 768-773. [CrossRef]

12. García-Faroldi, G.; Correa-Fiz, F.; Abrighach, H.; Berdasco, M.; Fraga, M.F.; Esteller, M.; Urdiales, J.L.; Sánchez-Jiménez, F.; Fajardo, I. Polyamines affect histamine synthesis during early stages of IL-3-induced bone marrow cell differentiation. J. Cell. Biochem. 2009, 108, 261-271. [CrossRef]

13. García-Faroldi, G.; Rodríguez, C.E.; Urdiales, J.L.; Pérez-Pomares, J.M.; Dávila, J.C.; Pejler, G.; Sánchez-Jiménez, F.; Fajardo, I. Polyamines Are Present in Mast Cell Secretory Granules and Are Important for Granule Homeostasis. PLoS ONE 2010, 5 , e15071. [CrossRef]

14. Acosta-Andrade, C.; Lambertos, A.; Urdiales, J.L.; Sánchez-Jiménez, F.; Peñafiel, R.; Fajardo, I. A novel role for antizyme inhibitor 2 as a regulator of serotonin and histamine biosynthesis and content in mouse mast cells. Amino Acids 2016, 48, 2411-2421. [CrossRef]

15. Fernández-Reina, A.; Urdiales, J.L.; Sánchez-Jiménez, F. What We Know and What We Need to Know about Aromatic and Cationic Biogenic Amines in the Gastrointestinal Tract. Foods 2018, 7, 145. [CrossRef]

16. Sánchez-Jiménez, F.; Ruiz-Pérez, M.V.; Urdiales, J.L.; Medina, M.A. Pharmacological potential of biogenic amine-polyamine interactions beyond neurotransmission. Br. J. Pharmacol. 2013, 170, 4-16. [CrossRef] [PubMed]

17. Phillips, R.S. Chemistry and diversity of pyridoxal-5'-phosphate dependent enzymes. Biochim. Biophys. Acta Proteins Proteom. 2015, 1854, 1167-1174. [CrossRef] [PubMed]

18. Wilson, M.P.; Plecko, B.; Mills, P.B.; Clayton, P.T. Disorders affecting vitamin B6 metabolism. J. Inherit. Metab. Dis. 2019, 42, 629-646. [CrossRef] [PubMed]

19. Panula, P.; Chazot, P.L.; Cowart, M.; Gutzmer, R.; Leurs, R.; Liu, W.L.S.; Stark, H.; Thurmond, R.L.; Haas, H.L. International Union of Basic and Clinical Pharmacology. XCVIII. Histamine Receptors. Pharmacol. Rev. 2015, 67, 601-655. [CrossRef] [PubMed]

20. Simons, F.E.R. Advances in H1-Antihistamines. N Engl. J. Med. 2004, 351, 2203-2217. [CrossRef]

21. Alexander, S.P.H.; Christopoulos, A.; Davenport, A.P.; Kelly, E.; Marrion, N.V.; Peters, J.A.; Faccenda, E.; Harding, S.D.; Pawson, A.J.; Sharman, J.L.; et al. The Concise Guide to Pharmacology 2017/18: G protein-coupled receptors. Br. J. Pharmacol. 2017, 174, S17-S129. [CrossRef] [PubMed]

22. Tiligada, E.; Ennis, M. Histamine pharmacology: From Sir Henry Dale to the 21st century. Br. J. Pharmacol. 2020, 177, 469-489. [CrossRef]

23. Moriguchi, T.; Takai, J. Histamine and histidine decarboxylase: Immunomodulatory functions and regulatory mechanisms. Genes Cells 2020, 25, 443-449. [CrossRef]

24. Zhao, C.M.; Chen, D.; Yamada, H.; Dornonville De La Cour, C.; Lindström, E.; Persson, L.; Håkanson, R. Rat stomach ECL cells: Mode of activation of histidine decarboxylase. Regul. Pept. 2003, 114, 21-27. [CrossRef]

25. Olmo, M.T.; Rodríguez-Agudo, D.; Medina, M.A.; Sánchez-Jiménez, F. The pest regions containing C-termini of mammalian ornithine decarboxylase and histidine decarboxylase play different roles in protein degradation. Biochem. Biophys. Res. Commun. 1999, 257, 269-272. [CrossRef] [PubMed]

26. Rodríguez-Agudo, D.; Olmo, M.T.; Sánchez-Jiménez, F.; Medina, M.Á. Rat Histidine Decarboxylase Is a Substrate for m-Calpain in Vitro. Biochem. Biophys. Res. Commun. 2000, 271, 777-781. [CrossRef] [PubMed]

27. Fleming, J.V.; Fajardo, I.; Langlois, M.R.; Sánchez-Jiménez, F.; Wang, T.C. The C-terminus of rat L-histidine decarboxylase specifically inhibits enzymic activity and disrupts pyridoxal phosphate-dependent interactions with L-histidine substrate analogues. Biochem. J. 2004, 381, 769-778. [CrossRef]

28. Furuta, K.; Nakayama, K.; Sugimoto, Y.; Ichikawa, A.; Tanaka, S. Activation of histidine decarboxylase through post-translational cleavage by caspase-9 in a mouse mastocytoma P-815. J. Biol. Chem. 2007, 282, 13438-13446. [CrossRef]

29. Fennell, L.M.; Fleming, J. V Differential processing of mammalian l-histidine decarboxylase enzymes. Biochem. Biophys. Res. Commun. 2014, 445, 304-309. [CrossRef]

30. Rodríguez-Caso, C.; Rodríguez-Agudo, D.; Moya-García, A.A.; Fajardo, I.; Medina, M.Á.; Subramaniam, V.; Sánchez-Jiménez, F. Local changes in the catalytic site of mammalian histidine decarboxylase can affect its global conformation and stability. Eur. J. Biochem. 2003, 270, 4376-4387. [CrossRef]

31. Fleming, J.V.; Sánchez-Jiménez, F.; Moya-García, A.A.; Langlois, M.R.; Wang, T.C. Mapping of catalytically important residues in the rat l-histidine decarboxylase enzyme using bioinformatic and site-directed mutagenesis approaches. Biochem. J. 2004, 379, 253-261. [CrossRef] [PubMed]

32. Moya-García, A.A.; Medina, M.Á.; Sánchez-Jiménez, F. Mammalian histidine decarboxylase: From structure to function. Bioessays 2005, 27, 57-63. [CrossRef] 
33. Komori, H.; Nitta, Y.; Ueno, H.; Higuchi, Y. Purification, crystallization and preliminary X-ray analysis of human histidine decarboxylase. Acta Crystallogr. Sect. F Struct. Biol. Cryst. Commun. 2012, 68, 675-677. [CrossRef]

34. Moya-García, A.A.; Ruiz-Pernía, J.; Martí, S.; Sánchez-Jiménez, F.; Tuñón, I. Analysis of the decarboxylation step in mammalian histidine decarboxylase. A computational study. J. Biol. Chem. 2008, 283, 12393-12401. [CrossRef]

35. Caro-Astorga, J.; Fajardo, I.; Ruiz-Pérez, M.V.; Sánchez-Jiménez, F.; Urdiales, J.L. Nascent histamine induces $\alpha$-synuclein and caspase-3 on human cells. Biochem. Biophys. Res. Commun. 2014, 451, 580-586. [CrossRef]

36. Chen, D.; Aihara, T.; Zhao, C.M.; Håkanson, R.; Okabe, S. Differentiation of the Gastric Mucosa I. Role of histamine in control of function and integrity of oxyntic mucosa: Understanding gastric physiology through disruption of targeted genes. Am. J. Physiol. Gastrointest. Liver Physiol. 2006, 291. [CrossRef] [PubMed]

37. Sánchez-Jiménez, F.; Montañez, R.; Correa-Fiz, F.; Rodríguez-Caso, C.; Urdiales, J.L.; Aldana, J.F.; Medina, M.Á. The usefulness of post-genomics tools for characterization of the amine cross-talk in mammalian cells. Biochem. Soc. Trans. 2007, 35, 381-385. [CrossRef] [PubMed]

38. Valent, P.; Akin, C.; Hartmann, K.; Nilsson, G.; Reiter, A.; Hermine, O.; Sotlar, K.; Sperr, W.R.; Escribano, L.; George, T.I.; et al. Mast cells as a unique hematopoietic lineage and cell system: From Paul Ehrlich's visions to precision medicine concepts. Theranostics 2020, 10, 10743-10768. [CrossRef] [PubMed]

39. Nishimura, K.; Okamoto, M.; Shibue, R.; Mizuta, T.; Shibayama, T.; Yoshino, T.; Murakami, T.; Yamaguchi, M.; Tanaka, S.; Toida, T.; et al. KLF4 is required for suppression of histamine synthesis by polyamines during bone marrow-derived mast cell differentiation. PLoS ONE 2020, 15, e0229744. [CrossRef] [PubMed]

40. Kanerva, K.; Lappalainen, J.; Mäkitie, L.T.; Virolainen, S.; Kovanen, P.T.; Andersson, L.C. Expression of Antizyme Inhibitor 2 in Mast Cells and Role of Polyamines as Selective Regulators of Serotonin Secretion. PLoS ONE 2009, 4, e6858. [CrossRef] [PubMed]

41. Ramos-Molina, B.; Lambertos, A.; Peñafiel, R. Antizyme Inhibitors in Polyamine Metabolism and Beyond: Physiopathological Implications. Med. Sci. 2018, 6, 89. [CrossRef] [PubMed]

42. Yatsunami, K.; Ohtsu, H.; Tsuchikawa, M.; Higuchi, T.; Ishibashi, K.; Shida, A.; Shima, Y.; Nakagawa, S.; Yamauchi, K.; Yamamoto, M. Structure of the L-histidine decarboxylase gene. J. Biol. Chem. 1994, 269, 1554-1559. [CrossRef]

43. Höcker, M.; Zhang, Z.; Koh, T.J.; Wang, T.C. The regulation of histidine decarboxylase gene expression. Yale J. Biol. Med. 1996, 69, 21-33. [PubMed]

44. Ai, W.; Liu, Y.; Langlois, M.; Wang, T.C. Kruppel-like Factor 4 (KLF4) Represses Histidine Decarboxylase Gene Expression through an Upstream Sp1 Site and Downstream Gastrin Responsive Elements. J. Biol. Chem. 2004, 279, 8684-8693. [CrossRef] [PubMed]

45. Ai, W.; Liu, Y.; Wang, T.C. Yin yang 1 (YY1) represses histidine decarboxylase gene expression with SREBP-1a in part through an upstream Sp1 site. Am. J. Physiol. Gastrointest Liver Physiol. 2006, 290. [CrossRef]

46. Kuramasu, A.; Saito, H.; Suzuki, S.; Watanabe, T.; Ohtsu, H. Mast cell-/basophil-specific transcriptional regulation of human L-histidine decarboxylase gene by CpG methylation in the promoter region. J. Biol. Chem. 1998, 273, 31607-31614. [CrossRef]

47. Correa-Fiz, F.; Reyes-Palomares, A.; Fajardo, I.; Melgarejo, E.; Gutiérrez, A.; García-Ranea, J.A.; Medina, M.A.; Sánchez-Jiménez, F. Regulatory cross-talk of mouse liver polyamine and methionine metabolic pathways: A systemic approach to its physiopathological consequences. Amino Acids 2012, 42, 577-595. [CrossRef] [PubMed]

48. Hirasawa, N. Expression of Histidine Decarboxylase and Its Roles in Inflammation. Int. J. Mol. Sci. 2019, 20, 376. [CrossRef]

49. Schwelberger, H.G.; Ahrens, F.; Fogel, W.A.; Sánchez-Jiménez, F. Histamine metabolism. In Histamine H4 Receptor: A Novel Drug Target in Immunoregulation and Inflammation; Stark, H., Ed.; Versita: Berlin, Germany, 2013; pp. 63-102. ISBN 9788376560564.

50. Horton, J.R.; Sawada, K.; Nishibori, M.; Zhang, X.; Cheng, X. Two polymorphic forms of human histamine methyltransferase: Structural, thermal, and kinetic comparisons. Structure 2001, 9, 837-849. [CrossRef]

51. Schwelberger, H.G. Histamine N-methyltransferase (HNMT) enzyme and gene. In Histamine: Biology and Medical Aspects; Falus, A., Grosman, N., Darvas, Z., Eds.; SpringMed. Publishing: Budapest, Hungary, 2004; pp. 53-59. ISBN 9789639456396.

52. Wang, L.; Yan, L.; McGuire, C.; Kozak, C.A.; Wang, M.; Kim, U.J.; Siciliano, M.; Weinshilboum, R.M. Mouse histamine Nmethyltransferase: cDNA cloning, expression, gene cloning and chromosomal localization. Inflamm. Res. 2001, 50, 300-308. [CrossRef]

53. Reyes-Palomares, A.; Montañez, R.; Sánchez-Jiménez, F.; Medina, M.A. A combined model of hepatic polyamine and sulfur amino acid metabolism to analyze S-adenosyl methionine availability. Amino Acids 2012, 42, 597-610. [CrossRef]

54. Rodríguez-Caso, C.; Montañez, R.; Cascante, M.; Sánchez-Jiménez, F.; Medina, M.Á. Mathematical modeling of polyamine metabolism in mammals. J. Biol. Chem. 2006, 281, 21799-21812. [CrossRef] [PubMed]

55. Biebl, M.; Klocker, J.; Perkmann, R.; Kolbitsch, C.; Klingler, P.; Drasche, A.; Klingler, A.; Fraedrich, G.; Schwelberger, H.G. Heparin-induced diamine oxidase release into the circulation in pigs. Inflamm. Res. 2002, 51, S93-S94. [CrossRef] [PubMed]

56. Arige, V.; Agarwal, A.; Khan, A.A.; Kalyani, A.; Natarajan, B.; Gupta, V.; Reddy, S.S.; Barthwal, M.K.; Mahapatra, N.R. Regulation of Monoamine Oxidase B Gene Expression: Key Roles for Transcription Factors Sp1, Egr1 and CREB, and microRNAs miR-300 and miR-1224. J. Mol. Biol. 2019, 431, 1127-1147. [CrossRef]

57. Maslinski, C.; Fogel, W.A. Catabolism of histamine. In Histamine and Histamine Antagonists; Uvnäs, B., Ed.; Springer: Berlin/Heidelberg, Germany, 1991; pp. 165-189. ISBN 9783642758409.

58. Schwelberger, H.G.; Feurle, J.; Houen, G. New tools for studying old questions: Antibodies for human diamine oxidase. J. Neural. Transm. 2013, 120, 1019-1026. [CrossRef] [PubMed] 
59. Fogel, W.A. Mucosal mono- and polyamine oxidase activities in digestive tract are distributed complementary to diamine oxidase. J. Neural. Transm. Suppl. 1990, 32, 345-349. [CrossRef] [PubMed]

60. Cai, Z.; Yan, L.-J. Protein Oxidative Modifications: Beneficial Roles in Disease and Health. J. Biochem. Pharmacol. Res 2013, 1, 15-26. [PubMed]

61. Nagy, J.A.; Benjamin, L.; Zeng, H.; Dvorak, A.M.; Dvorak, H.F. Vascular permeability, vascular hyperpermeability and angiogenesis. Angiogenesis 2008, 11, 109-119. [CrossRef]

62. Halpern, B.N.; Guillaumat, L.; Cruchaud, S. Action of histamine and synthetic antihistamines on the capillary permeability of the blood-brain barrier. Sem Hop 1948, 24, 2564.

63. Miles, A.A. Increased permeability of skin capillaries produced by histamine in guinea-pigs. J. Physiol. 1951, 114, 35.

64. Gözsy, B.; Kátó, L. Changes in permeability of the skin capillaries of rats after histamine depletion with 48/80, dextran or egg white. J. Physiol. 1957, 139, 1-9. [CrossRef]

65. Majno, G.; Palade, G.E.; Schoefl, G.I. Studies on Inflammation II. The Site of Action of Histamine and Serotonin along the Vascular Tree: A Topographic Study. J. Biophys. Biochem. Cytol. 1961, 11, 607-626. [CrossRef]

66. Fredholm, B.B.; Meng, H.C.; Oberg, B.; Rosell, S. Vascular and metabolic effects of histamine and compound 48/80 in subcutaneous adipose tissue. Br. J. Pharmacol. 1968, 34, 197-198.

67. Buckley, I.K.; Ryan, G.B. Increased vascular permeability. The effect of histamine and serotonin on rat mesenteric blood vessels in vivo. Am. J. Pathol. 1969, 55, 329-347. [PubMed]

68. van Nieuw Amerongen, G.P.; Draijer, R.; Vermeer, M.A.; van Hinsbergh, V.W.M. Transient and Prolonged Increase in Endothelial Permeability Induced by Histamine and Thrombin. Circ. Res. 1998, 83, 1115-1123. [CrossRef]

69. Ikeda, K.; Utoguchi, N.; Makimoto, H.; Mizuguchi, H.; Nakagawa, S.; Mayumi, T. Different Reactions of Aortic and Venular Endothelial Cell Monolayers to Histamine on Macromolecular Permeability: Role of cAMP, Cytosolic Ca2+ and F-actin. Inflammation 1999, 23, 87-97. [CrossRef]

70. Guo, M.; Breslin, J.W.; Wu, M.H.; Gottardi, C.J.; Yuan, S.Y. VE-cadherin and $\beta$-catenin binding dynamics during histamine-induced endothelial hyperpermeability. Am J. Physiol. 2008, 294, C977-C984. [CrossRef]

71. Rozenberg, I.; Sluka, S.H.M.; Rohrer, L.; Hofmann, J.; Becher, B.; Akhmedov, A.; Soliz, J.; Mocharla, P.; Borén, J.; Johansen, P.; et al. Histamine H1 Receptor Promotes Atherosclerotic Lesion Formation by Increasing Vascular Permeability for Low-Density Lipoproteins. Arterioscler. Thromb. Vasc. Biol. 2010, 30, 923-930. [CrossRef] [PubMed]

72. Karlstedt, K.; Jin, C.; Panula, P. Expression of histamine receptor genes HRH3 and HRH4 in rat brain endothelial cells. Br. J. Pharmacol. 2013, 170, 58-66. [CrossRef]

73. Adderley, S.P.; Zhang, X.E.; Breslin, J.W. Involvement of the H1 Histamine Receptor, p38 MAP Kinase, Myosin Light Chains Kinase, and Rho/ROCK in Histamine-Induced Endothelial Barrier Dysfunction. Microcirculation 2015, 22, 237-248. [CrossRef]

74. Ashina, K.; Tsubosaka, Y.; Nakamura, T.; Omori, K.; Kobayashi, K.; Hori, M.; Ozaki, H.; Murata, T. Histamine Induces Vascular Hyperpermeability by Increasing Blood Flow and Endothelial Barrier Disruption In Vivo. PLoS ONE 2015, 10, e0132367. [CrossRef]

75. Mikelis, C.M.; Simaan, M.; Ando, K.; Fukuhara, S.; Sakurai, A.; Amornphimoltham, P.; Masedunskas, A.; Weigert, R.; Chavakis, T.; Adams, R.H.; et al. RhoA and ROCK mediate histamine-induced vascular leakage and anaphylactic shock. Nat. Commun. 2015, 6, 6725. [CrossRef] [PubMed]

76. Kugelmann, D.; Rotkopf, L.T.; Radeva, M.Y.; Garcia-Ponce, A.; Walter, E.; Waschke, J. Histamine causes endothelial barrier disruption via Ca2+-mediated RhoA activation and tension at adherens junctions. Sci. Rep. 2018, 8, 13229. [CrossRef]

77. Si, H.; Wang, J.; Meininger, C.J.; Peng, X.; Zawieja, D.C.; Zhang, S.L. Ca2+ release-activated Ca2+ channels are responsible for histamine-induced $\mathrm{Ca} 2+$ entry, permeability increase, and interleukin synthesis in lymphatic endothelial cells. Am. J. Physiol. Circ. Physiol. 2020, 318, H1283-H1295. [CrossRef]

78. Grimsey, N.J.; Lin, Y.; Narala, R.; Rada, C.C.; Mejia-Pena, H.; Trejo, J. G protein-coupled receptors activate p38 MAPK via a non-canonical TAB1-TAB2- and TAB1-TAB3-dependent pathway in endothelial cells. J. Biol. Chem. 2019, 294, 5867-5878. [CrossRef]

79. Melgarejo, E.; Medina, M.Á.; Sánchez-Jiménez, F.; Botana, L.M.; Domínguez, M.; Escribano, L.; Orfao, A.; Urdiales, J.L. (-)Epigallocatechin-3-gallate interferes with mast cell adhesiveness, migration and its potential to recruit monocytes. Cell Mol. Life Sci. 2007, 64, 2690-2701. [CrossRef] [PubMed]

80. Melgarejo, E.; Medina, M.Á.; Sánchez-Jiménez, F.; Urdiales, J.L. Epigallocatechin gallate reduces human monocyte mobility and adhesion in vitro. Br. J. Pharmacol. 2009, 158, 1705-1712. [CrossRef] [PubMed]

81. Lopez-Garcia, C.; Lopez-Contreras, A.J.; Cremades, A.; Castells, M.T.; Peñafiel, R. Transcriptomic Analysis of Polyamine-Related Genes and Polyamine Levels in Placenta, Yolk Sac and Fetus During the Second Half of Mouse Pregnancy. Placenta 2009, 30, 241-249. [CrossRef] [PubMed]

82. Kim, K.; Ramirez, V.D. Dibutyryl cyclic adenosine monophosphate stimulates in vitro luteinizing hormone-releasing hormone release only from median eminence derived from ovariectomized, estradiol-priMed. rats. Brain Res. 1985, 342, 154-157. [CrossRef]

83. Soares, M.J.; Iqbal, K.; Kozai, K. Hypoxia and Placental Development. Birth Defects Res. 1309, 109, 1309-1329. [CrossRef]

84. Maintz, L.; Schwarzer, V.; Bieber, T.; Ven, K.; van der Novak, N. Effects of histamine and diamine oxidase activities on pregnancy: A critical review. Hum. Reprod. Update 2008, 14, 485-495. [CrossRef] 
85. Crouse, M.S.; Greseth, N.P.; McLean, K.J.; Crosswhite, M.R.; Pereira, N.N.; Ward, A.K.; Reynolds, L.P.; Dahlen, C.R.; Neville, B.W.; Borowicz, P.P.; et al. Maternal nutrition and stage of early pregnancy in beef heifers: Impacts on hexose and AA concentrations in maternal and fetal fluids. J. Anim Sci. 2019, 97, 1296-1316. [CrossRef] [PubMed]

86. Pyzlak, M.; Szewczyk, G.; Szukiewicz, D.; Szczesniak, A. Histamine influence on apoptosis in trophoblast cell cultures. Inflamm. Res. 2010, 59, 213-215. [CrossRef]

87. Komi, D.E.A.; Shafaghat, F.; Haidl, G. Significance of mast cells in spermatogenesis, implantation, pregnancy, and abortion: Cross talk and molecular mechanisms. Am. J. Reprod Immunol. 2020, 83, e13228. [CrossRef]

88. Faas, M.M.; Vos, P. De Innate immune cells in the placental bed in healthy pregnancy and preeclampsia. Placenta 2018, 69, 125-133. [CrossRef]

89. Medina, M.Á.; Quesada, A.R.; Núñez de Castro, I.; Sánchez-Jiménez, F. Histamine, polyamines, and cancer. Biochem. Pharmacol. 1999, 57, 1341-1344. [CrossRef]

90. Medina, V.A.; Coruzzi, G.; Lamas, D.J.M.; Massari, N.; Adami, M.; Levi-Schaffer, F.; Ben-Zimra, M.; Schwelberger, H.; Rivera, E.S. Histamine in cancer. In Histamine H4 Receptor: A Novel Drug Target in Immunoregulation and Inflammation; Versita: Berlin, Germany; Volume 9788376560, pp. 259-308. ISBN 9788376560.

91. Hanahan, D.; Weinberg, R.A. Hallmarks of cancer: The next generation. Cell 2011, 144, 646-674. [CrossRef] [PubMed]

92. Krauth, M.-T.T.; Agis, H.; Aichberger, K.J.; Simonitsch-Klupp, I.; Müllauer, L.; Mayerhofer, M.; Böhm, A.; Horny, H.-P.P.; Valent, P. Immunohistochemical detection of histidine decarboxylase in neoplastic mast cells in patients with systemic mastocytosis. Hum. Pathol. 2006, 37, 439-447. [CrossRef] [PubMed]

93. Rivera, E.S.; Cricco, G.P.; Engel, N.I.; Fitzsimons, C.P.; Martín, G.A.; Bergoc, R.M. Histamine as an autocrine growth factor: An unusual role for a widespread mediator. Semin. Cancer Biol. 2000, 10, 15-23. [CrossRef] [PubMed]

94. Höcker, M.; Rosenberg, I.; Xavier, R.; Henihan, R.J.; Wiedenmann, B.; Rosewicz, S.; Podolsky, D.K.; Wang, T.C. Oxidative Stress Activates the Human Histidine Decarboxylase Promoter in AGS Gastric Cancer Cells*. J. Biol. Chem. 1998, 273, 23046-23054. [CrossRef] [PubMed]

95. Urdiales, J.L.; Mates, J.M.; Núñez de Castro, I.; Sánchez-Jiménez, F. Chlorpheniramine inhibits the ornithine decarboxylase induction of Ehrlich carcinoma growing in vivo. FEBS Lett. 1992, 305, 260-264. [CrossRef]

96. Medina, V.A.; Rivera, E.S. Histamine receptors and cancer pharmacology. Br. J. Pharmacol. 2010, 161, 755-767. [CrossRef]

97. Martinel Lamas, D.J.; Croci, M.; Carabajal, E.; Crescenti, E.J.V.; Sambuco, L.; Massari, N.A.; Bergoc, R.M.; Rivera, E.S.; Medina, V.A. Therapeutic potential of histamine $\mathrm{H} 4$ receptor agonists in triple-negative human breast cancer experimental model. Br. J. Pharmacol. 2013, 170, 188-199. [CrossRef]

98. Massari, N.A.; Medina, V.A.; Martinel Lamas, D.J.; Cricco, G.P.; Croci, M.; Sambuco, L.; Bergoc, R.M.; Rivera, E.S. Role of H4 receptor in histamine-mediated responses in human melanoma. Melanoma Res. 2011, 21, 395-404. [CrossRef]

99. Pós, Z.; Sáfrány, G.; Müller, K.; Tóth, S.; Falus, A.; Hegyesi, H. Phenotypic Profiling of Engineered Mouse Melanomas with Manipulated Histamine Production Identifies Histamine H2 Receptor and Rho-C as Histamine-Regulated Melanoma Progression Markers. Cancer Res 2005, 65, 4458-4466. [CrossRef] [PubMed]

100. Suarez-Carmona, M.; Lesage, J.; Cataldo, D.; Gilles, C. EMT and inflammation: Inseparable actors of cancer progression. Mol. Oncol. 2017, 11, 805-823. [CrossRef] [PubMed]

101. Carmeliet, P. Angiogenesis in life, disease and medicine. Nature 2005, 438, 932-936. [CrossRef] [PubMed]

102. Rodríguez-Caso, L.; Reyes-Palomares, A.; Sánchez-Jiménez, F.; Quesada, A.R.; Medina, M.Á. What is known on angiogenesisrelated rare diseases? A systematic review of literature. J. Cell Mol. Med. 2012, 16, 2872-2893. [CrossRef] [PubMed]

103. Fraser, R.A.; Simpson, J.G. Ciba Foundation Symposium 100-Development of the Vascular System. Novartis Found. Symp. 2008, 100, 120-131. [CrossRef]

104. Barnhill, R.L.; Ryan, T.J. Biochemical Modulation of Angiogenesis in the Chorioallantoic Membrane of the Chick Embryo. J. Investig. Dermatol. 1983, 81, 485-488. [CrossRef] [PubMed]

105. Marks, R.M.; Roche, W.R.; Czerniecki, M.; Penny, R.; Nelson, D.S. Mast cell granules cause proliferation of human microvascular endothelial cells. Lab. Investig. 1986, 55, 289-294.

106. Thompson, W.D.; Brown, F.I. Quantitation of histamine-induced angiogenesis in the chick chorioallantoic membrane: Mode of action of histamine is indirect. Int. J. Microcirc. Clin. Exp. 1987, 6, 343-357.

107. Sörbo, J.; Jakobsson, A.; Norrby, K. Mast-cell histamine is angiogenic through receptors for histamine1 and histamine2. Int. J. Exp. Pathol. 1994, 75, 43-50. [PubMed]

108. Qin, L.; Zhao, D.; Xu, J.; Ren, X.; Terwilliger, E.F.; Parangi, S.; Lawler, J.; Dvorak, H.F.; Zeng, H. The vascular permeabilizing factors histamine and serotonin induce angiogenesis through TR3/Nur77 and subsequently truncate it through thrombospondin-1. Blood 2013, 121, 2154-2164. [CrossRef]

109. Norrby, K. Evidence of a dual role of endogenous histamine in angiogenesis. Int. J. Exp. Pathol. 1995, 76, 87-92.

110. Norrby, K. Mast cells and angiogenesis. APMIS 2002, 110, 355-371. [CrossRef] [PubMed]

111. Varricchi, G.; Rossi, F.W.; Galdiero, M.R.; Granata, F.; Criscuolo, G.; Spadaro, G.; de Paulis, A.; Marone, G. Physiological Roles of Mast Cells: Collegium Internationale Allergologicum Update 2019. Int. Arch. Allergy Immunol 2019, 179, 247-261. [CrossRef]

112. Komi, D.E.A.; Wöhrl, S.; Bielory, L. Mast Cell Biology at Molecular Level: A Comprehensive Review. Clin. Rev. Allergy Immunol. 2020, 58, 342-365. [CrossRef] [PubMed] 
113. Laakkonen, J.P.; Lappalainen, J.P.; Theelen, T.L.; Toivanen, P.I.; Nieminen, T.; Jauhiainen, S.; Kaikkonen, M.U.; Sluimer, J.C.; Ylä-Herttuala, S. Differential regulation of angiogenic cellular processes and claudin- 5 by histamine and VEGF via PI3K-signaling, transcription factor SNAI2 and interleukin-8. Angiogenesis 2017, 20, 109-124. [CrossRef] [PubMed]

114. Lu, Q.; Wang, C.; Pan, R.; Gao, X.; Wei, Z.; Xia, Y.; Dai, Y. Histamine synergistically promotes bFGF-induced angiogenesis by enhancing VEGF production via H1 receptor. J. Cell. Biochem. 2013, 114, 1009-1019. [CrossRef] [PubMed]

115. Natori, T.; Sata, M.; Nagai, R.; Makuuchi, M. Cimetidine inhibits angiogenesis and suppresses tumor growth. BioMed. Pharmacother. 2005, 59, 56-60. [CrossRef]

116. Medina, M.Á. Systems biology for molecular life sciences and its impact in biomedicine. Cell Mol. Life Sci. 2013, 70, 1035-1053. [CrossRef]

117. Ocaña, M.C.; Martínez-Poveda, B.; Quesada, A.R.; Medina, M.Á. Metabolism within the tumor microenvironment and its implication on cancer progression: An ongoing therapeutic target. Med. Res. Rev. 2019, 39, 70-113. [CrossRef] [PubMed]

118. Kuperstein, I.; Bonnet, E.; Nguyen, H.-A.; Cohen, D.; Viara, E.; Grieco, L.; Fourquet, S.; Calzone, L.; Russo, C.; Kondratova, M.; et al. Atlas of Cancer Signalling Network: A systems biology resource for integrative analysis of cancer data with Google Maps. Oncogenesis 2015, 4, e160. [CrossRef] [PubMed]

119. Rodchenkov, I.; Babur, O.; Luna, A.; Aksoy, B.A.; Wong, J.V.; Fong, D.; Franz, M.; Siper, M.C.; Cheung, M.; Wrana, M.; et al. Pathway Commons 2019 Update: Integration, analysis and exploration of pathway data. Nucleic. Acids Res. 2019, 48, D489-D497. [CrossRef]

120. Hornbeck, P.V.; Chabra, I.; Kornhauser, J.M.; Skrzypek, E.; Zhang, B. PhosphoSite: A bioinformatics resource dedicated to physiological protein phosphorylation. Proteomics 2004, 4, 1551-1561. [CrossRef]

121. Perfetto, L.; Briganti, L.; Calderone, A.; Perpetuini, A.C.; Iannuccelli, M.; Langone, F.; Licata, L.; Marinkovic, M.; Mattioni, A.; Pavlidou, T.; et al. SIGNOR: A database of causal relationships between biological entities. Nucleic Acids Res. 2016, 44, D548-D554. [CrossRef]

122. Cui, Q.; Ma, Y.; Jaramillo, M.; Bari, H.; Awan, A.; Yang, S.; Zhang, S.; Liu, L.; Lu, M.; O'Connor-Mccourt, M.; et al. A map of human cancer signaling. Mol. Syst. Biol. 2007, 3. [CrossRef]

123. Türei, D.; Korcsmáros, T.; Saez-Rodriguez, J. OmniPath: Guidelines and gateway for literature-curated signaling pathway resources. Nat. Methods 2016, 13, 966-967. [CrossRef]

124. Ruiz-Perez, M.; Sanchez-Jimenez, F.; Alonso, F.; Segura, J.; Marquez, J.; Medina, M. Glutamine, Glucose and other Fuels for Cancer. Curr. Pharm. Des. 2014, 20, 2557-2579. [CrossRef]

125. Tomasi, M.L.; Ryoo, M.; Skay, A.; Tomasi, I.; Giordano, P.; Mato, J.M.; Lu, S.C. Polyamine and methionine adenosyltransferase 2A crosstalk in human colon and liver cancer. Exp. Cell Res. 2013, 319, 1902-1911. [CrossRef] [PubMed]

126. Medina, M.Á.; Urdiales, J.L.; Rodríguez-Caso, C.; Ramírez, F.J.; Sánchez-Jiménez, F. Biogenic Amines and Polyamines: Similar Biochemistry for Different Physiological Missions and Biomedical Applications. Crit. Rev. Biochem. Mol. Biol. 2008, 38, 23-59. [CrossRef] [PubMed]

127. Abrighach, H.; Fajardo, I.; Sánchez-Jiménez, F.; Urdiales, J.L. Exploring polyamine regulation by nascent histamine in a humantransfected cell model. Amino Acids 2010, 38, 561-573. [CrossRef] [PubMed]

128. Sanchez-Jimenez, F.; Reyes-Palomares, A.; Moya-Garcia, A.; Ranea, J.; Medina, M. Biocomputational Resources Useful for Drug Discovery Against Compartmentalized Targets. Curr. Pharm. Des. 2014, 20, 293-300. [CrossRef]

129. Pezzuto, A.; Carico, E. Role of HIF-1 in Cancer Progression: Novel Insights. A Review. Curr. Mol. Med. 2019, 18, 343-351. [CrossRef] [PubMed]

130. Pino-Ángeles, A.; Reyes-Palomares, A.; Melgarejo, E.; Sánchez-Jiménez, F. Histamine: An undercover agent in multiple rare diseases? J. Cell Mol. Med. 2012, 16, 1947-1960. [CrossRef] [PubMed] 